Julia Bray*

\title{
Reading "the exotic" and Organising the Production of Knowledge: al-Tanūkhī on Indians and Their Elephants
}

https://doi.org/10.1515/asia-2017-0003

\begin{abstract}
Al-Muhassin ibn 'Alī al-Tanūkhī (327-384/939-994) included a number of items about Indian elephants and Indians in his compilations of stories and anecdotes Nishwār al-muhāẹara ("The table-talk of a Mesopotamian judge") and al-Faraj ba'da al-shidda ("Deliverance follows adversity"), both of which approach the organisation of knowledge in novel ways and on a new scale. This paper lists the items, summarises their contents, and explains al-Tanūkhī's interest in elephants in the light of an autobiographical narrative. It then surveys the ethnology of his Indian stories, which are often told by sailors or merchants, and compares them in content and style with the sailors' tales in Akhbār al-Sīn wa-l-Hind ("Accounts of China and India”), with al-Bīrūnī's observations in $M \bar{a}$ li-l-Hind ("India"), and with an alleged shift from factuality to fabulation said to be taking place at around this time, which is exemplified by 'Ajā'ib al-Hind ("The Wonders of India"). Close reading shows how al-Tanūkhī's portrayal of elephants as rational agents of divine providence is managed, and how exotic humans are proved to play their part in God's plan like any others. Al-Tanūkhī's response to "the exotic" leads us to question it as a category of enquiry in the light not only of cultural studies but also of its content and of the multiple Arabic literary fields to which apparent exotica may belong. The significance of the organisation of Faraj and Nishwär is reassessed. We conclude that alTanūkhì's purpose in composing the works was not to impart facts as such, exotic or otherwise, or cultural judgements, but to teach people how to read stories properly so as to understand the kind of truth they convey, an endeavour which may be compared to his contemporary al-Āmidī's systematic approach to training his readers to become critical readers of poetry.
\end{abstract}

Keywords: Indians in third/ninth to fifth/eleventh-century Arabic ethnology, elephants, "the exotic", al-Tanūkhī, al-Āmidī, the systematic teaching of close reading

*Corresponding author: Julia Bray, The Oriental Institute, University of Oxford, Oxford, UK. E-mail: julia.bray@orinst.ox.ac.uk 
The Basran and Baghdadi author al-Muhassin ibn 'Alī al-Tanūkhī (327-384/ 939-994) wrote two large and lastingly popular compilations of stories and anecdotes, Nishwār al-muhāḍara ("Table-talk of a Mesopotamian judge") and al-Faraj ba'da al-shidda ("Deliverance follows adversity"), both of which adopt novel approaches to the organisation of existing knowledge. Faraj, al-Tanūkhī tells his readers, is the most comprehensive treatment to date of the topic of adversity and deliverance. Its organisation, he says in his preface, reflects honest, coherent and methodical procedures of authorship, for unlike three earlier works with similar titles, his book always acknowledges materials used by its predecessors and includes nothing that is not pertinent to the topic. It subdivides the topic into themed chapters meant to cover all combinations of adversity and deliverance, and each item is placed in the chapter where it belongs. ${ }^{1}$ In Nishwār, on the contrary, al-Tanūkhī acknowledges no precursors. Its contents are original, being taken almost entirely from oral sources. ${ }^{2}$ Nishwär too was intended to be comprehensive, covering the spectrum of human types (such as "Votaries. Ascetics. Eremites. Sufis. Self-torturers"), as al-Tanūkhī tells his readers in the first of the work's four extant introductions ${ }^{3}$ (to volumes one, two, three and eight of al-Shālji's edition. The fourth introduction is fragmentary.). Originally, each volume would have been "an independent unit, which the reader can enjoy apart from the others," with "a preface indicating the nature of the anecdotes embodied in all the volumes, their scope, and the motive which led me to collect them ... and an epitome of [the book's] contents," ${ }^{4}$ but what survives of the work contains little or no signposting and proceeds by loose association. In terms of organisational method, therefore, Faraj and Nishwār could be seen as opposites, or as complementary. Their contents, however, do occasionally overlap.

Thus in both compilations, al-Tanūkhī included a number of accounts of, and stories about, Indians and Indian elephants, and while some items occur in only one of the compilations, others are found in both. Here is a list of them, with their distribution in Nishwār (N) and Faraj (F) by volume (Roman numerals), story number, ${ }^{5}$ and page, and with references to the English translation of

1 al-Tanūkhī 1978, vol.1: 52-57.

2 al-Tanūkhi 1922: 1, 9, al-Tanūkhī 1971-1973, vol.2: 7, vol.3: 7, vol.4: 7.

3 al-Tanūkhi 1922: 2-4.

4 al-Tanūkhi 1922: 10.

5 'Abbūd al-Shāljī numbered the stories in the eight volumes of his edition of Nishwār consecutively by volume. Those in the five volumes of his edition of Faraj are numbered consecutively across volumes. 
Nishwār by D.S. Margoliouth. ${ }^{6}$ Pieces about India or Indians are marked I; pieces about elephants are marked $\mathbf{E}$, and those that are about both are marked I $+\mathbf{E}$.

Pieces that occur only in Nishwār:

I NI, no.55: 110-11 = al-Tanūkhi 1922: 61-63 (political wisdom: how an Indian rebel became king).

I + E NVIII, no.90: 205-208 = al-Tanūkhī 1930: 382-384 (how wild elephants are caught and tamed in India).

I + E NVIII, no.91: 208 = al-Tanūkhi 1930: 384 (the king of Champa and his 2,000 elephants).

I + E NVIII, no.92: 209 = al-Tanūkhi 1930: 384-385 (how the king of Champa uses an elephant in executions).

E NVIII, no.93: $210=$ al-Tanūkhi 1930: 385 (the elephant that al-Tanūkhī saw as a boy in Basra).

(To these can be added a piece that will not be discussed in this paper:

I NIII, no.126: 194 = al-Tanūkhī 1932: 64 (a friend of a friend of al-Tanūkhī dreams of a holy ascetic, in appearance "like a man from Sind").

Pieces that occur only in Faraj:

I + E FIV, no.424: 174-176, from Chapter Nine, "Those by beasts given chase/ Spared death by God's grace” (a herd of elephants make an elephant hunter kill a snake for them, and reward him with the contents of the elephants' graveyard). $^{7}$

Pieces that occur both in Nishwār and in Faraj:

I + E NI, no.54: 108-109 (omitted by Margoliouth in al-Tanūkhi 1922) = FIV, no.415: 150-151, from Chapter Nine, “Those by beasts given chase ...” (after an Indian rebel kills the king's elephant with his bare hands, the sacred harlots ${ }^{8}$ advise the king to take him into his service).

I NVIII, no.94: 211-216 = al-Tanūkhi 1930: 385-388= FIV, no.466: 300-306, from Chapter Twelve, "Those resorting, in fear, to flight and hiding/Who found instead security, blessings, and joy abiding” (the autobiography of an Indian prince: how he lost his throne to a usurper and regained it).

6 Margoliouth published his translation of Part One of Nishwār in book form in 1922. His translations of Parts Eight and Two appeared in Islamic Culture from 1929 to 1932.

7 al-Damīrī’s (d.808/1405) Ḥayāt al-ḥayawān al-kubrā s. v. "al-fil” adds to al-Tanūkhī's version, dictated by Abū l-Faraj al-Ișfahānī, of the story of how the King of China bought off Alexander the Great (FII, no.235: 340-342) the detail, absent from al-Shāljī's edition of Faraj, that at their last meeting, the King of China was mounted on "a huge elephant”, Damīrī 1353, vol.2: 229.

8 "A vizier" is substituted for the harlots in al-Damīī 1353, vol.2: 230. 
I NVIII, no.95: 217 = al-Tanūkhi 1930: 531, and NVIII, no.96: 218-211 = alTanūkhi 1930: 531-533 = FIII, no.366: 399-402, from Chapter Eight, "Those about to be killed/Whose death was forestalled” (Indian carrion-eaters; murderous Indian bandits and a native Muslim trader).

E NIII, no.127: 195-197 = al-Tanūkhi 1932: 64-66 = FIV, no.409: 129-132, from Chapter Nine, "Those by beasts given chase ...” (a shipwrecked Sufi swears never to eat elephant flesh if he is delivered, and is delivered by an elephant). ${ }^{9}$

There are several ways of looking at these pieces from the point of view of the organisation and classification of knowledge, both within al-Tanūkhī's own literary economy and as part of the wider fourth/tenth-century literary scene. As a provisional or argumentative classification, I have applied the label "exotic" to them, because of their affinities with travellers' and sailors' tales, which are often treated as genres in modern scholarship and which several scholars claim underwent a significant shift from factual reporting to literarisation or fabulation ${ }^{10}$ at around the time al-Tanūkhī was writing. ${ }^{11}$ Al-Tanūkhī's stories about India and elephants, some of which, as we shall see, seem to have seafarers as their sources, have not so far, to my knowledge, been included in discussions of the process.

Within a larger frame of enquiry, the term "exotic" reminds us in shorthand how western encounters with non-Europeans have essentialised them, describing them as impenetrably different and "other" and narrating their behaviour as deviant, and of the numerous ways in which, starting with Victor Segalen's Essai sur l'exotisme: une esthétique du divers (written 1904 to 1918, first published 1978) and in the wake of Edward Said's Orientalism (1978), cultural and postcolonial studies have worked to expose the knowledge and power systems that rest on western observing and narrating of the oriental "other". Medieval Muslims also encountered eastern "others." Did they bring the same sort of exoticising, disempowering gaze to bear on them? is a question that obviously arises. In modern scholarship, "l'étrange et le merveilleux", the strange and the marvellous, is the usual categorisation applied to medieval Muslim accounts or depictions of foreigners and unfamiliar phenomena. ${ }^{12}$ But it has remained

9 Retold by Damīī 1353, vol.2: 228, abridging Abū Nu'aym al-Ișfahānī’s (d.430/1038) biography of a certain Abū 'Abd Allāh al-Qalānisī in Hilyat al-awliyā'. In Abū Nu'aym's version, the narrator-protagonist is al-Qalānisī instead of al-Tanūkhīs Ibrāhīm al-Khawwāṣ (d.291/903); the elephant is a female, and she helps al-Qalānisī to dismount from her by "stretching out a leg”, al-Ișfahānī 1932-1938, vol.10: 161. Other versions are discussed in Van Gelder 2003.

10 The term used by Mackintosh-Smith, al-Sīrāfī 2014: 13.

11 E.g. Miquel 2001 [1967]: 117-118, de Planhol 2000: 102.

12 See Miquel 2001 [1975]: 484-485, Arkoun 1978, Bernus-Taylor and Jail 2001. 
undeveloped, and largely untouched by cultural theory. An exception is Nizar Hermes' discussion of the fourth/tenth-century Akhbār al-Șin wa-l-Hind ("Accounts of China and India"; see below) which, however, rejects the notion that Muslims too were "Orientalists" when they described other eastern peoples, ${ }^{13}$ and endorses Nabil Matar's assertion that "The Arabic travel accounts cannot ... be approached through the theoretical models ... with which European accounts have been studied by writers as different as Stephen Greenblatt, Edward Said, and Gayatri Spivak. They belong to a tradition that is different not only in its history but epistemology." 14 Most recently, Syrinx van Hees criticises western scholars for assigning features of Arabic historical writing to the category of the strange and marvellous, on the grounds that the term is usually misapplied or lacking in content. ${ }^{15}$ Matar and van Hees, however, are talking about seventeenth-century Ottoman and fourteenth to sixteenth-century Mamluk writers respectively, while Hermes' critique bears on only one text from the period that concerns us, Akhbār al-Sīn wa-l-Hind. To test both the notion of "the exotic", the idea of a fourth/tenth-century shift from factuality to fabulation, and Hermes' claim that postcolonial premises do not apply to Akhbār al-Sīn wa-l-Hind and its like, I will compare the ethnology and narrative of al-Tanūkhī's Indian stories, and their content and style, with similar subject matter in Akhbār al-Șin wa-l-Hind, al-Bīrūnì's slightly later Mā li-l-Hind ("India”) and 'Ajā'ib alHind ("The Wonders of India", attributed to Buzurg ibn Shahriyār).

To start with, I will look at how al-Tanūkhī first became interested in elephants, as this may explain why he later went on to record information about them. In the year 339/950-1, when he was a boy of eleven or twelve, he saw an elephant in Basra, where he lived (NVIII, no.93). Even in adulthood, looking back, he is emphatic about having seen it with his own eyes: anā ra'aytu ... filan latîfan, "I saw for myself ... a fine elephant."16 It was a gift to the first Buyid ruler of Iraq, Mu'izz al-Dawla (r. 334-356/945-967), from a ruler of Oman (șāḥib 'Umān) whose name al-Tanūkhī does not mention. He does not explain how it was transported from Oman, or where it came from originally, but says

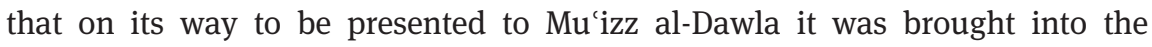
courtyard of al-Tanūkhì's father's house. (He was a man of importance: as the local qadi, he had acted as a power-broker to the Buyids, ${ }^{17}$ and he was a close

13 Hermes 2013: 217.

14 Hermes 2013: 218, quoting Matar 2003: xxxii.

15 Van Hees 2017.

16 Margoliouth 1930: 385 translates lațif as "small”.

17 Miskawayh 1920-1921, vol.4: 388, 430-431, 435. 
friend of Mu'izz al-Dawla's vizier al-Muhallabī. ${ }^{18}$ ) Although al-Tanūkhī stresses that he and his father's household saw this elephant (humila ilā dārinā faudkhila ilā șahninā fa-ra'aynāhu, "it was brought to our house and into our courtyard, where we saw it"), what he tells us about it is not what he saw, but rather what he heard: he was told that, as it was being ridden through the Friday Market in Basra, the elephant-handlers-fayyālūn, in the plural-shouted at a little boy to get out of its way; but he lost his head (dahisha), and the elephant swung him up on to its trunk and passed him to his handlers, "who demanded payment to put down the now screaming and panic-stricken child"(fa-șâha lșabiyyu wa-țāra 'aqluhu fa-mā anzalūhu illā bi-darāhim). Margoliouth translates this as: "the boy cried and was distracted, and they had to give him some dirhems before he would let them put him down,"19 but a closer reading, as I have rendered it, suggests that the mahouts were taking advantage of the child's terror rather than trying to soothe him. Close reading should also take account of what is not said. We should note that it is left to the reader to speculate on the reason for the elephant's behaviour. Was it colluding with its handlers, having been trained to take children hostage for money? Or was it clever enough to think up the trick on its own initiative? Some days later, "after someone threw a stone at it”-I follow Margoliouth's reading: adrakat al-fila șakhratun; al-Shāljī reads adrakat al-fila dajratun, "something upset it"-the same elephant was reported to have grabbed hold of a lad, wrapped its trunk around him, tossed him in the air, "caught him on its tusk and run it through him, goring him to death" (istaqbalahu bi-nābihi fa-adkhalahu fi jismihi fa-qatalahu). ${ }^{20}$ From the point of view of the animal's behaviour and how it may be interpreted, the detail on which al-Shāljī and Margoliouth differ is crucial. If the elephant was "upset”, as in al-Shāljī's reading, there is no connection between cause and effect: the lad that it gores is a random victim. But if the lad provoked the elephant, as Margoliouth's reading has it, we can begin to see not only rational cause and effect but consistency in the animal's behaviour. It punishes the small boy who fails to get out of its way by giving him a fright and holding him to ransom. The older, deliberately spiteful boy is punished with death. ${ }^{21}$

18 al-Tha'ālibī 1983, vol.2: 393-394, 399-400.

19 al-Tanūkhi 1930: 385.

20 Margoliouth translates: "got him inside its body", inverting the referents of the pronouns, al-Tanūkhi 1930: 385.

21 In the section on elephants in Kitāb al-Hayawān ("The Book of Living Things"), al-Jāhiz (d. ca. 255/868) cites two anecdotes to similar effect. In one, an elephant shows its resentment of an incivility. What is not explained is the advanced knowledge of language that the elephant would have needed in order to understand the insult, but much later in the section, al-Jāhiz says "a friend" has told him that Indian elephants do understand the Indian language. A 
This elephant anecdote, which is unique in being narrated by al-Tanūkhī himself, comes in Nishwār at the end of a sequence of items concerning elephants (NVIII, nos. 90-93) which bears no thematic relation to what comes before, ${ }^{22}$ and at the beginning of a second sequence, about India and Indians (NVIII, nos. 94-96), which has only a tangential thematic relation to the items that come after. ${ }^{23}$ How does this fit with the general organisation of Nishwār? Nishwār is extant only in parts, with further, discrete quotations surviving in later authors, and except for the first section and part of the second, there is only one MS witness to each of the four surviving portions. ${ }^{24}$ This means that our insight into its structure is limited. Al-Tanūkhī reiterates in the four surviving prefaces that its organisation is implicit, not explicit ${ }^{25}$; but Margoliouth observes that "The content of [Part Eight] is miscellaneous according to the author's plan, but less so than that of the first volume; unless indeed the copyist has omitted some matters." ${ }^{26}$ Because together they form a selfcontained series within Part Eight, I think it is legitimate to try and identify some common defining features and underlying categories within the elephant and India sequences. At the same time, I will compare the items in the sequences with similar materials in Akhbār al-Ṣin wa-l-Hind, of which Book One dates to 237/851-2, while Book Two, redacted by Abū Zayd al-Sīrāfī, mentions various dates in the first half of the fourth/tenth century, ${ }^{27}$ ' $A j \bar{a}^{\prime} i b$ al-Hind, of the same general date as Book Two, and al-Bīrūnì's Mā li-l-Hind, written around 1030 A.D.

Let us note from the outset that in none of his elephant stories does alTanūkhì describe the animals' appearance. Perhaps he thought that any educated reader would have known what they looked like. Instead, he concentrates on presenting elephant behaviour. The first item in the first elephant sequence

second story told him by "a very judicious seafarer" shows that elephants are clever at taking their revenge. Even if the story is not factually true, says al-Jāhiz, it is consistent with what people think is plausible in respect of elephants, al-Jāhiz 1938-1945, vol.7: 87, 225, 228-229.

22 The two immediately preceding items, nos. 88 and 89, are linked to each other and to nos. 90-92 by their source, Abū l-Husayn. No. 88 is about an Andalusī who travelled to Iraq to study with al-Jāhị, was insulted by him at their first meeting, and pleaded "four things" in his own defence. No. 89 is a witty saying about "four types" of personality.

23 Again, there is a link through Abū l-Hiusayn, the source of nos. 97-99. Nos. 97 and 98 are about cunning Iraqi thieves and their equally cunning victims; no. 99 is about an old man seducing a young stranger.

24 al-Tanūkhi 1971-1973, vol.1, Editor's Preface: 7-8,13-16.

25 al-Tanūkhi 1971-1973, vol.1: 1-14, vol.2: 7-8, vol.3: 7-8, vol.8: 7.

26 al-Tanūkhī 1929: 488.

27 al-Sīrāfî 2014, Introduction: 6, 12. 
in Nishwār is a detailed, narrative, but un-plotted, description of how wild elephants are captured and trained as war elephants for Indian kings (NVIII, no.90). This is followed by a brief, non-narrative, item of information: the king of Sanf has two thousand elephants, which stretch over about a parasang when they are mustered (idhā kharajat) (NVIII, no.91). Al-Tanūkhī does not situate Șanf, but says it is the place that "Șanfi wood" (al-'ūd al-șanfi) comes from. According to Yāqūt (d.626/1229), it is "either in India or in China" (and the wood, which is burned for its scent, is of poor quality). ${ }^{28}$ In translating the item, Margoliouth refers to Henry Yule and A.C. Burnell, Hobson-Jobson, s. n. "Champa", which distinguishes the original Champa, "a city and kingdom on the Ganges", and the seventh-century colony in Indochina, "certainly the Sanf of the Arab navigators 600 years later."29 The Sanf of the anonymous Book One of Akhbār al-Șin wa-l-Hind is the one in Indochina. ${ }^{30}$ According to the medieval to early modern European sources cited in Hobson-Jobson, both Champas seem to have been famous for elephants, making it difficult to determine which is the Champa of NVIII, no.91. A third item (NVIII, no.92) describes how the king of Champa uses elephants to carry out executions, which they do in different ways, either tearing a man in half or crushing him, according to the verbal commands given by the mahout. Of these three items, the first was related to al-Tanūkhì by "Abū l-Ḥusayn", identified by al-Shāljī as 'Alī ibn Hishām ibn 'Abd Allāh, known as Ibn Abī Qayrāț/Qīrāț, a state scribe about whom nothing seems to be known except that he was employed in the treasury by the vizier Ibn al-Furāt, and subsequently worked for two more viziers, 'Alī ibn 'Isā and Ibn Muqla. ${ }^{31}$ "Abū l-Husayn" says that his information is what he heard people say "when I was in Tāna [now Mumbai] in India”. The two following items, each introduced by qāla sami'tu (“'I have heard,' he said”) presumably also go back to him, for following them, al-Tanūkhì's account of the elephant he saw in Basra is introduced in his own voice by the first-person declarative qultu.

After al-Tanūkhì's account of the elephant that he saw as a boy, his informant is again "Abū l-Husayn". The new sequence consists of three items about Indian manners, customs, and ethnic or social groups. (These are re-told in Faraj as two items which do not occur in sequence, FIV, no.466 and FIII, no.366.) The first item (NVIII, no. $94=$ FIV, no. 466) is a plotted narrative about an Indian prince who loses and regains his throne; it moves from the third to the first person and back again, and is told by a native Indian Muslim to "al-Faḍl ibn

28 Yāqūt 1990, vol.3: 489.

29 Yule/Burnell 1968 [1903]: 183-184.

30 al-Sīrāfì 2014: 34-35, 156.

31 See al-Tanūkhi 1978, vol.1: 322, n.1. 
Bāhmād of Sīrāf, who was famous for his sea voyages to the most distant lands", who in turn relates it to "Abū l-Ḥusayn" in the port of Sīrāf. In Nishwār, the native informant "told me ... that he had found himself somewhere in India where the king ..." So too in the Paris MS BN 3483 of Faraj; but in other MSS and al-Shāliji's edition, the chronology is not tied to the narrator and is indeterminate: "He told me that somewhere in India there was (or: had been) a king ..." The next two items (NVIII, nos.95 and 96, amalgamated in Faraj as FIII, no. 366) are related to "Abū l-Husayn" in Nishwār, but in Faraj they are told to "Abū lHasan Muhammad Ibn Shujā', the Baghdadi theologian”, with the prefixes: "In India, I saw (ra'aytu) people ...” and: “[In India], there are also people ...” These people are respectively carrion-eaters and murderous bandits. The carrion-eaters and their social interactions are only described, whereas the bandits' behaviour is first described, then illustrated by “Abū l-Ḥusayn's” (or Abū 1-Ḥasan’s) father's retelling of an incident in which a native Muslim escapes a bandit with the help of a carrion-eater. The confusion between "Abū l-Husayn", the state scribe Ibn Abī Qayrāt, if al-Shāljī's identification is correct, and "Abū lHasan” Ibn Shujā', the Baghdadi theologian, needs further research to resolve, if indeed it can be resolved. That either a state scribe or a theologian should have had close connections with the India trade lifts the type of story we are dealing with here out of automatic association with professional seafarers and the often automatic assumption that sailors spin "tall stories", 32 which may well be mistaken, and is hardly meaningful. A case in point is 'Ajā'ib al-Hind, attributed to a sea-captain, Buzurg ibn Shahriyār. For Xavier de Planhol, this is a collection of tall, entirely fantastic stories put together by a non-traveller. ${ }^{33}$ Maria Kowalska disagrees about the incidence of the fantastic, arguing that "fantastic elements ... occur only within the stories which were transmitted many times from many different informants", but she agrees with de Planhol that "Fantastic or semi-fantastic adventure stories dealing with exotic countries were not so much the work of travellers ... as of people who did not travel themselves, but who passed on tales told by travellers and transformed them ..."34 De Planhol himself makes another distinction, between sailors (unreliable), and "prudent" merchants, who are interested in facts. ${ }^{35}$ But Gabriel Ferrand, a translator of Akhbār al-Șin wa-l-Hind (to date it has atleast four French and four English translations), puts the work in far more suggestive perspective, which could also

32 See "Buzurg ibn Shahriyār"(R. Irwin) in Meisami and Starkey 1998, vol.1: 166-167 and de Planhol 2000: 94.

33 De Planhol 2000: 99-100.

34 Kowalska 1987-1988: 400.

35 De Planhol 2000: 94. 
apply to 'Ajā'ib al-Hind. The compiler of the second half of Akhbār al-Șin wa-lHind, Abū Zayd, he describes as "neither a traveller nor a sailor, simply a scholar interested in geography, who keeps abreast of the political and economic situation in India and China by questioning merchants [in his home town, the great port of Sīrāf], and records the latest discoveries of seafarers." ${ }^{36}$ By emphasising that what Abū Zayd writes down is breaking news, Ferrand casts him in the role of a proto-journalist, and this ultimately is the thrust of his "Orientalist" remark that "the Oriental is particularly prone to raise the simplest facts to the plane of the marvellous, and sailors and travellers are even more imaginative than their sedentary fellow-countrymen," which concludes: "But human nature everywhere has a craving for the sensational" ("En fait, l'humanité toute entière est avide de merveilleux"). "Sensational" seems the right way to render "merveilleux" in this context, and the shift in register avoids connotations of passive, naïve wonderment, and reminds us that this was a period of discovery and intellectual ferment.

At this point, we can make summary observations about the literary form of the items in the sequence that we have just surveyed (NVIII, nos. 90-96), and about their types of content:

the form may be either a narrative, or non-narrative, i. e. an item of information (as in the case of NVIII, 91 and 92). The narratives may be descriptions or stories, reported, witnessed or autobiographical, or some combination of these;

the content may bear on elephant behaviour, the interactions of humans and elephants, or on human behaviour.

Let us examine how elephant behaviour is presented, before moving on to human behaviour. In the elephant stories, there is no animal norm or term of comparison: elephant behaviour, psychology, or the ways in which humans use elephants or interact with them, are not discussed in relation to other animals. Whether explicitly or implicitly, elephant behaviour is shown to be motivated and comprehensible. It is described factually, and there is no hint that any aspect of elephant behaviour has been singled out because it is in some way symbolic of, or analogous to, anything else, although we may wonder about this (and will discuss the point later). Thus, in the first item in the Nishwär sequence, NVIII, no.90, because "elephants are very intelligent" (fihā min al-fitna amr 'azim), the only way to capture a wild elephant is to use as a lure "a tame,

36 "Abû Zayd Ḥasan de Sîrâf ... n'est ni voyageur, ni marin; c'est un simple érudit que la géographie interesse, qui se tient au courant de la situation politique et économique de l'Inde et de la Chine auprès des marchands, et enregistre les découvertes nouvelles des gens de la mer," Ferrand 1922: 13-14.

37 Ferrand 1922: 20-21. 
trained female which is very dainty and feminine" (unthā ahliyya mu'allama fihā fadl khanath wa-ta'nith). ${ }^{38}$ Her scent attracts the male; she caresses him with her trunk, and the two graze together for a month or so under the eyes of the concealed mahouts. When they judge that a bond of trust and intimacy (ulfa) has been established, the mahouts stealthily climb on to the female's back and ride her away. The male follows, and whenever he tries to attack the mahouts, the female strokes him with her trunk and distracts him. When they reach the city, vast crowds assemble to greet them and the male panics. The female stops him running away, and keeps doing so until he becomes used to humans. She likewise stops him taking fright when he is exposed to the sound of drums. Finally, he is fettered to four stakes and left to get hungry, with the female by his side. Once he will accept food (rice and ghee) from humans, he can be ridden, and is tame (yasiiru fi ḥukm al-ahlī), ${ }^{39}$ and will become a war elephant worth between ten thousand and a hundred thousand gold coins. ${ }^{40}$ We have already seen that, in the third item in the sequence, the trained elephants of the king of Sanf do not kill haphazardly, but on command, either tearing a man in half or crushing him (NVIII, no.92). In NVIII, no.90, the first item in the sequence, it is established that even an untrained elephant, or a half-trained one, whose behaviour is still governed by its instincts, behaves predictably and consistently. It seems to me, therefore, conclusive that, in the fourth and last item in the sequence, the elephant that al-Tanūkhī saw as a boy must have had a better motive than mere moodiness for picking someone out of a crowd and killing him: by placing the incident at the end of the sequence, al-Tanūkhī has laid the groundwork for us to deduce that it was retribution for an unprovoked attack.

In the stories about Indian humans, there are similarities with the literary treatment of elephants. The different social types described are not compared to a social norm, and, like the elephants, are not described physically. Each social type is defined, and the behaviour of individuals is illustrated in a way that is consistent with these characteristics. Ethnographic terms are explained as they occur. Thus, in the first item in the second Nishwār sequence (NVIII, no.94), the informant of the voyager al-Faḍl ibn Bāhmād al-Sīrāfī is a baysar, plural bayāsira, that is to say "a person born a Muslim in India," ${ }^{11}$ which explains his relationship to a foreign fellow-Muslim and his status as an authority on matters Indian. These Indian or Indian-resident Muslims are mentioned by alMas' 'ùdī as forming, in 304/916, "in the province of Lār which is in the States of

38 al-Tanūkhi 1971-1973, vol.8: 205.

39 al-Tanūkhi 1971-1973, vol.8: 208.

40 al-Tanūkhi 1971-1973, vol.8: 205.

41 An emended reading from Faraj. Nishwār reads "one of the wealthy” (mayāsīr). 
Ballaharā”, a community of some 10,000 settlers of various geographical origins. ${ }^{42} \mathrm{Al}-\mathrm{Mas}$ 'ūdī says this term also applies to native-born Indian Muslims, but their existence is not mentioned in the First Book of Akhbār al-Sīn wa l-Hind, which dates to only sixty years earlier (237/851-2), and whose author asserts, to the contrary: "I do not know of a single member of the [Chinese or Indian] races (al-farīqayn) who is a Muslim." "43 Some eighty years later, however, al-Bīrūnī speaks of native Indian Muslims (and of revolting customs which Islam has abolished). ${ }^{44}$ J.C. Wilkinson quotes later Arabic, lexical sources: “... Lisān al'Arab and Tāj al-'arūs (art. bayāsirah) ... say that the bayāsirah are a people (jīl) of Sind from whom the nawkhudās (ships' captains) recruited mercenary fighting sailors ... In the view of [Wilkinson] the bayāsirah [of Oman] are the vestigial souche of peoples who lived in the general area of the Gulf before the arrival of the Semitic and Indo-Aryan groups who came to dominate them." 45 Whether bayāsirah are different from metropolitan Muslims is not stated by al-Mas' $\bar{u} d \overline{1}$, al-Tanūkhī or al-Bīrūnī.

Al-Faḍl ibn Bāhmād al-Sīrāfî’s baysar informant describes how an Indian king, acting according to local custom and the dignity of his rank, never gave or took things face to face, but only with his hand behind his back, and that it is also a royal custom for princes to carry with them for emergencies, in a sort of waistcoat (șudra), a kingdom's worth of jewels wrapped in silk. ${ }^{46}$ These customs are two of the devices on which the plot of the baysar's story turns. When the king dies, the throne is seized by a usurper, and his son flees with his waistcoat. After nearly starving for seven days in the company of a selfish travelling companion, he makes for a judām, glossed as rustāq, "village," 47 and hires himself out as a labourer. There a wealthy woman, seeing him give and take with his hand behind his back, recognises him as a royal personage, and marries him. A traveller from his own country tells him that the people have killed the usurper and are seeking the true heir. The prince proves his identity, entrusts his vest and jewels to his wife in case he should be killed, but regains his throne

42 al-Mas'ūdī 1966-1979, vol.1: 248, § 515. Ballaharā is an Arabicised form of the Sanskrit title of several kings of a dynasty ruling in the Deccan from about 743 to 974 A.D. "The Arabic geographers from the mid-ninth to the second half of the tenth century ... mention the Ballahara king as the greatest of the kings of al-Hind ... Special attention is given to the king's large numbers of elephants", Wink 1990: 303-305.

43 al-Sīrāfĩ 2014: 62-63.

44 al-Bīrūnī 1887: 91.

45 Wilkinson 1974: 79. See also Wink 1990: 69, 71.

46 al-Tanūkhi 1971-1973, vol.8: 211.

47 Margoliouth notes: "The narrator is mistaken. The word gudam, Anglicized as [godown], means a storehouse", al-Tanūkhi 1930: 386. 
and sends for her. He now puts in motion elaborate measures to find the man who nearly let him starve, and having found him and given him a leaf of betel (tanbūl), a mark of great honour, reveals himself and showers him with favours. After the man has eaten with him, the king sends his wife to massage him until he falls asleep. When she has done so, he tells her the whole story, and says that the man is not sleeping but dead, explaining that "Indians have huge livers, and are well-known for their imagination (tawahhum). He has died of remorse for his past unkindness."

Before moving on to the ethnographic content of the next two items, we may note that this story has elements of both resolved and unresolved intertextuality. It has the schema of a faraj ba'da al-shidda story, and it does indeed appear as such in Faraj, Chapter Twelve, "Those resorting, in fear, to flight and hiding/ Who found instead security, blessings, and joy abiding"; but it could just as well be classed as a tale of just deserts, mukäfa'a, since the slow operation of retribution is as important a running element of the story's structure as the (double) reversal of the prince's status. A prominent motif with no structural role is the mutual trust between the prince and the wealthy woman who marries him and gives him her fortune to manage when he is destitute. This, and her recognition of him as a man out of the ordinary, recalls the relationship of the prophet Muhammad and Khadija, his first wife, who recognised his outstanding qualities, married him when he was an outcast, and whose wealth launched his career. Is the parallel deliberate, or is it coincidental? In either case, would a Muslim reader equate the mildness and decency that the prince displays in the course of the story with models of good Muslim behaviour? Or does the parallel suggest a more general, philosophical idea of human similarity across cultures? In fact, for the story to work, likeness and otherness both have to be allowed to operate. Even if the motif of conjugal trust does acculturate the story to some extent for Muslim readers, at the same time the words spoken by the prince to his wife at the story's conclusion emphasise that its motivation and psychology are culture-specific. I quote the speech in extenso in Margoliouth's translation: "The Indians have large livers, and their imagination is their most notable characteristic. The man was seized with regret because he had not been kind to me on that occasion, and this regret killed him. I had expected him to die before this of the mental sickness, regret, and vexation, which he imagined or experienced, and indeed they have killed him." 48

At first reading, the lengthy explanation might appear to attenuate the shock ending of the preceding narrative. In fact, by providing a rational, natural explanation of a mystifying event, it gives the reader an extra surprise. This is a

48 al-Tanūkhi 1930: 388. 
device familiar from medical stories, a genre to which this tale of foreign customs belongs by virtue of its ending, and which links it intertextually to other families of tales of surprising diagnoses of natural causes: detective stories and escape stories, of both of which this tale also has elements. ${ }^{49}$ What all these types of tale have in common is that they rest on a process of scientific universalisation, which in this story is paradoxically posited on ethnic idiosyncrasy.

The next two items in the Nishwär sequence are fused into one in Faraj, where they are assigned to Chapter Eight under the elastic rubric "Those about to be killed/Whose death was forestalled." We have already noted the difficulty of identifying al-Tanūkhī's informant for these items, which are rich in ethnographic content that can be compared directly with information to be found in both books of Akhbār al-Ṣin wa-l-Hind and al-Bīrūnī's India. The first item describes the "eaters of carrion" who are accounted unclean by all other Indians. They beat drums hung round their necks to warn people of their proximity, and if they fail to do so and touch someone, that person may kill them with impunity (NVIII no.95 = beginning of FIII, no.366). They are shunned and live apart, "subsisting on what they can hunt (ma'āshuhum min al-șayd)." (Does this contradict their being carrion-eaters? Is the sentence inserted so as to construct a parallel with the description of the bābūwāniyya which follows?) The Arabic term for them is the garbled janādhiyya or jabāriyya, which can be identified with cāṇ̣̂āla. ${ }^{50}$ Al-Bīrūnī mentions jandāl under several headings in the context of caste. He says that they are sweepers and are shunned, ${ }^{51}$ but does not mention the right to kill them in Chapter 71 "On punishments and expiations". 52

Then, in the next item in Nishwär, there are the murderous pickpockets whose name is Arabised variously as bābūwāniyya ${ }^{53}$ or bānuwāniyya. ${ }^{54}$ Hunters of men instead of animals, they "subsist entirely from hunting down (yaștādūna; note the echo of the word just applied to the jabariyya) merchants who are Muslims or dhimmis," $" 55$ and if the merchants cry out for help, no-one dares try to rescue them lest the thieves instantly kill both their victims and themselves, "because of their well-known belief concerning killing," 56 which is not explained. In Book Two of Akhbār al-Ṣin wa-l-Hind, it is said that, in Ceylon,

49 For the interrelationship of these story types, and examples, see Bray 2006.

50 I am grateful to my colleague Professor Chris Minkowski for this identification.

51 al-Bīrūnī 1887: 49.

52 al-Bīrūnī 1887: 280.

53 al-Tanūkhi 1971-1973, vol.8: 218.

54 al-Tanūkhi 1978, vol.3: 399.

55 See Wink 1990: ch.3 on the origins and religions of trading diasporas in India.

56 al-Tanūkhi 1971-1973, vol.8: 218 = al-Tanūkhi 1978, vol.3: 400. 
in the past, "certain ... men"-who are not given any special name-"used to ... lunge at the most eminent [Arab] merchant they could get hold of ... pull the dagger on him ... all in the middle of a crowd of people who could do nothing at all to stop him, because if they tried to snatch the merchant from him, the abductor would kill both his captive and himself ... the abductor would demand a ransom ..." 57 The same information is illustrated in Nishwār and Faraj by the story of a Muslim merchant who is held to ransom by a bābūwānī (NVIII no.95 = FIII no.366). On their way to the merchant's house to collect the ransom, they pass through a village of jabāriyya. The merchant breaks free and seeks refuge in the house of a jabārī, who takes him under his protection. The jabāri and the bābūwāni argue over him (from opposite sides of the street, because of the jabārī 's uncleanness), the bābūwānì threatening that he and his kind will slaughter every jabāri they meet if he is cheated of his "livelihood" (rizq). They agree to meet outside the village, the jabārī armed with his bow and fifty arrows (this chimes in with the assertion that the jabārīs subsist by hunting), the merchant hanging on to him literally for dear life. Although like all jabāris he is an "infallible archer", each arrow he shoots is cut in two by the brigand, until, with only two arrows left, he hits on a ruse to distract his attention and shoots him through the heart.

In terms of ethnographic content, these pieces are very much in the idiom of Book One of Akhbār al-Șin wa-l-Hind, which does not comment or pass judgement on foreign ways, but is essentially practical and descriptive: it tells travellers what to expect and what they need to know. In Book Two, by contrast, we find comments such as this on the people of al-Aghbāb: "Sexual immorality $(f a s \bar{a} d)$ is rife in this place, among both women and men, and is not prohibited ... The religious scholars (mashāyikh) in Sīrāf used to forbid their people from going on trading voyages to this region, and particularly the young men," this, on the wantonness of Chinese registered harlots (zawānī): "We praise God for the guidance by which he has purified us from such temptations (fitan)."59 Later, for al-Bīrūnī, India is, socially, a topsy-turvy world where they do everything the other way round from "us" in a way that "we" would consider astonishing: wa-fì siyar al-Hind mā yukhālifu rusūm ahl bilādinā mukhālafatan tașīru 'indanā 'ujūba. ${ }^{60}$

57 al-Sīrāfì 2014: 113. 'Ajā'ib al-Hind 1883-1886: 151-153, no. XCIX tells of wandering bands of Indian brigands who attack rich merchants both native and foreign and hold them to ransom. They are not given a special name.

58 al-Sīrāfĩ 2014: 117.

59 al-Sīrāfí 2014: 73.

60 al-Bīrūnī 1887: 89. 
In Book Two of Akhbār al-Ṣin wa-l-Hind, however, ethnographic matter is interspersed not only with moralising comments, but with a substantial amount of narrative, most of which teaches political lessons; for example the story about the stupid new king of al-Qamār (the Khmers), who is envious of the king of alZabāj (Java) and wishes for his head in a dish. Hearing of this, the king of alZabāj instead takes his head, which affords an everlasting warning to his successors. In another tale of like for like, a Khurasani merchant complains that one of the king of China's eunuchs has seized his goods. The eunuch's guilt is proved; the king spares his life because of his long service, but demotes him to guarding the royal cemeteries, where he will "manage the dead, because you have failed in your management of the living." Of more general moral application, there is the story of the Indian fool who shows off by cutting off his own head. ${ }^{61}$ We might ask whether, here, narrative is another way of organising ethnographic material, or whether the ethnography provides cues for storytelling; but this way of looking at things is superficial. It passes over questions about cognition and epistemology-what it is such stories are trying to represent and why-as well as artistic questions of verisimilitude and poetic truth-how they are trying to do so. André Miquel felt that, in Book Two of Akhbār al-Sīn wal-Hind, narrative and the marvellous had gained the upper hand, along with a Muslim sanctimoniousness that robs its ethnographic observations of their cultural content, ${ }^{62}$ but Miquel's frame of literary reference, the all-embracing term $a d a b$, seems to be used by him simply to mean a literising register. It does not carry enough meaning to be of use in interrogating texts. For this, the focus should be shifted to questions of technique and purpose. I suggest the relationship set up in Book Two between information and illustration or explanation should be compared closely with what is found in other sorts of Arabic writing of the period, such as the kinds of stories to which NVIII, no.94 is intertextually related, or those narratives which pick up cues in poems and turn them into fully-fledged biographical episodes, ${ }^{63}$ on which (and on stories such as ours) alJāhiz might have passed the same verdict as on a story about elephants biding their time in order to take their revenge: "Even if the report is not factually true,

61 al-Sīrāfĩ 2014: 91-97, 99-101, 111.

62 Miquel 2001 [1967]: 124-125, 2001 [1975]: 124-125.

63 Compare Blachère (1952-1966), vol.3: 629-642, which dismantles the anecdotes attached to women's names in the poetry of 'Umar ibn Abī Rabī'a in Kitāb al-Aghānī ("The Book of Songs", compiled during the first half of the fourth/tenth century by al-Tanūkhï's teacher Abū l-Faraj alIșfahānī), with Petit and Voisin (1993), which refashions them into a continuous psychological biography. Both approaches respond to the kind of questions that 'Abbasid life writing tacitly asks about what we can know or tell about the lives of "others" on the basis of fragmentary evidence. 
people would not have claimed such a thing of the elephant alone among animals unless they believed it to be consistent with what the elephant's nature made plausible (in kāna bāțilan fa-innahum lam yanhalū-l-fila hādhihi-l-niḥlata dūna ghayrihi mina-l-dawwābi illā wa-fìhi 'indahum mā yahtamilu dhālika wayaliqu bihi)." ${ }^{64}$ This is not a rule for drawing a line between fact and fantasy or ideology, but an admission that complex mental processes are involved in trying to sift through the probabilities that anything we are told might be true, given that our judgements are based on evidence which has already been shaped by other people's perceptions and preconceptions.

In Nishwār, al-Tanūkhī seems to be conscious of this drive towards narrative elaboration and how readers might interpret it, and has his own comment on it. In an Indian story about a rebel who overthrows a king (NI no.55), ${ }^{65}$ he repeats what a learned judge of his acquaintance, Abū Bakr Aḥmad ibn Sayyār, was told by an experienced Arabian seafarer, who claimed to have been told it by an Indian informant. It is a story that exemplifies political wisdom. The clever rebel, having overthrown a foolish king, becomes king in his place. Wishing to consolidate his rule, he summons wise men from all of his dominions, and charges ten of them and ten members of his own household with telling him what his faults are as a ruler. They reply that his only fault is his lack of lineage-"everything about you is new," they say. The former rebel points out to them that he is the founder of a dynasty, and that if he rules wisely his dynasty will last as long as that of his predecessor, who was the last of his line. At this, the wise men prostrate themselves before him, "which was their habit," says the narrator, "if they approved of something and were convinced by it." ${ }^{\circ 6}$ But al-Tanūkhī is unimpressed by either the wisdom or the exoticism of this tale. He comments to the learned judge: "The Arabs said this long ago in two words, without long foreign parables (al-mathal al-țawìl al-'ajamì). Two men were arguing which was the better, and one said to the other: 'My lineage begins with me, whereas yours ends with you.",67

Al-Tanūkhī nevertheless transmits three stories that are "foreign parables" inasmuch as they turn on the social customs of the Indians. The stories of the prince who regains his throne and of the rebel who founds a dynasty are two of them. The third is the story of a bold and popular rebel who comes to a city to make terms with its king (NI, no.54), which in Nishwār forms a mini-sequence

64 Al-Jāhiz 1938-1945, vol.7: 87, 225, 228-229. See note 21 above.

65 This story is preceded by another Indian story about a rebel who gains a king's favour, but is otherwise unrelated thematically to the surrounding, brief, anecdotal items.

66 al-Tanūkhi 1971-1973, vol.1: 111.

67 al-Tanūkhi 1971-1973, vol.1: 111. 
with that of the rebel who founded a dynasty, and in Faraj (FIV, no.415) is one of a suite of twenty-three tales of escape from animals which includes three elephant stories. The rebel's path crosses that of the king's own special elephant, one of several that were there to add to the festiveness of the occasion. When the rebel refuses to get out of its way, the king's elephant wraps its trunk around him and tries to kill him by dashing him against the ground. This happens three times, and each time the rebel keeps hold of the elephant's trunk and survives unscathed. The third time, the elephant itself drops deadthe prolonged pressure on its trunk has suffocated it. At this point, the sacred harlots advise the king to befriend the rebel whose strength and cleverness, they tell him, will be an ornament (jamāl) to his realm. The Arab narrator uses the Arabic word qihāb, and explains that these are women who give themselves freely and openly in the [temple of] ('inda) "the idol" (budd) as an act of worship, on which account they are regarded as ascetics (zuhhād) and holy women ('ubbād). They also have a legal role as public witnesses ('udūl) and as advisers to the judge (hākim). The narrator-who is identified as "a Yemeni sailor who had been to India and China"-passes no comment, but (in Nishwār) betrays his confusion at this combination of feminine and (to him) exclusively masculine roles by mixing masculine and feminine verbs and pronouns (in Faraj the grammar is standardised.) "Idol prostitutes" are also mentioned in Book Two of Akhbār al-Șin wa-l-Hind, but they have no judicial functions. They simply contribute from their earnings to the upkeep of the temple. Abū Zayd al-Sīrāfī comments: “And God, glorious and mighty is He, we praise for the guidance He chose for us and by which He purified us from the sins of the unbelievers!" 68 By contrast, it is notable that, like his sources, alTanūkhī make no such comments.

The best-known of al-Tanūkhī's tales of the exotic could be classed as zoological. Like the tale of the rebel and the king's elephant, they occur in Faraj in the chapter on escapes from animals. The salient point of two of them is that they demonstrate elephants' powers of reasoning. One is found in Nishwār as well as in Faraj: the story of the Sufi and the elephant's child (NIII, no.127 = FIV, no.409). A Sufi tells how he and a band of shipwrecked Sufis are washed up on an unknown shore. In hopes of fending off starvation, each of them vows to God to make some act of renunciation. Something moves the narrator to swear "never to eat the flesh of an elephant." The band then scatter in search of food, and find an elephant calf, which they contrive to cook and eat. The narrator, true to his oath, abstains. Almost immediately, a huge elephant appears and hunts down the Sufis one by one, sniffing them all over before

68 al-Sīrāfī 2014: 119. 
tearing them limb from limb. Finally, only the narrator is left. The elephant sniffs him three times, and instead of killing him, sets him on its back and carries him to safety.

The other such zoological story, the story of the elephants' graveyard, appears only in Faraj (FIV, no. 424), and like the account in Nishwār of how wild elephants are captured and trained for war, it explicitly mentions their intelligence (fitna). ${ }^{69}$ The story is well-known, according to al-Tanūkhīs informant, and goes back two generations. It is told to him on the authority of Bahraynīs who are familiar with India. The narrator is a man who hunts elephants for a living, not only for their tusks, but also for their skins. He begins by describing how he kills them with poisoned arrows, hiding in a tree and picking off the last of a herd as they leave their watering-hole. On one occasion, while he is waiting for an elephant he has shot to die, the herd return and surround the wounded animal. The largest elephant observes the wound and the arrow protruding from it. Once it is dead, the herd set about searching the trees for the hunter. The largest elephant finds him and knocks his tree to the ground. When it sees his bow and arrows, it gently wraps its trunk around him and lifts him on to its back. The whole herd gallops back to the watering-hole, where an enormous, spitting snake is in possession. The largest elephant sets the hunter on the ground and points to the snake. The hunter shoots it. The elephant stamps on it, puts the hunter on its back again, and gallops off, followed by the herd, to a great forest which is the graveyard of innumerable elephants. The largest elephant organises a task force of elephants to collect all the tusks. They carry their loads, and the hunter, back to civilisation, and leave him there with the ivory, the sale of which makes him so rich that he has no further need to hunt elephants.

By depicting elephants as rational beings in Nishwār, al-Tanūkhī is assimilating them to a general scheme of things that is essentially rational. ${ }^{70}$ In Faraj, elephants additionally have a providential role: a negative but enabling one in the tale of the rebel who wins the king's favour by killing his elephant with his bare hands; a positive one in the two cases we have just seen. Indeed, in these last two stories, elephants are made into moral as well as rational agents, avenging their child's death, but deliberately avoiding killing the innocent in the story of the shipwrecked Sufis, and, in the story of the hunter, distinguishing between the greater and the lesser evils of the snake and the hunter, refraining for the greater good of the community from avenging themselves on the hunter, and rewarding him in such a way as to prevent him from harming them in

69 al-Tanūkhi 1971-1973, vol.4: 176.

70 Bray 2004. 
future. This tale could be viewed as a political parable: the hunter makes himself useful to the elephants whom he has harmed rather as the rebel made himself useful to the king. More than this, the elephant herd could be seen as the model of a virtuous community: guided by the wisdom of the largest elephant, all act together for the common good. Under the generic veneers of the traveller's tale and the zoological wonder-tale, this, then, is also a philosophical allegory. (That these elephants are being used to think with by being given moral agency is very clear if we compare them with the elephants described in 'Ajä'ib al-Hind, which are domesticated animals, trained to go shopping for their owners, to do the housework, prepare food, draw water and pick their own fodder. ${ }^{71}$ Intelligent creatures, but not independent agents, they carry out human tasks but do nothing that human beings could learn from.)

By manipulating literary form, al-Tanūkhī is able to use elephants to argue for the wisdom of the creator of such wise beasts. Narrative is an especially powerful and persuasive tool, for it serves to anthropomorphise and universalise elephants, whether through story-telling, by showing the rational purposefulness of their voluntary behaviour, or through description, by showing how almost humanly intelligible their involuntary responses are (the wild male elephant is tamed by his clever and seductive lover rather as al-Tanūkhī's selfish and silly young men, in Chapter Thirteen of Faraj, are civilised by accomplished and beautiful slave women). ${ }^{72}$

Exotic human beings also bear witness to the universality of providence. Their differences from Muslims are not disparaged, for their strange affects (an imagination so vivid that it causes them to die of remorse) and habits (honouring harlots as holy women fit to counsel judges and kings) are precisely what make them proofs, or agents, of providence. Here it is the shading from ethnographic description into narrative, or from narrative into descriptionthe merging of the descriptions of the jabāriyya and bābūwāniyya with the story of the Muslim merchant; the insertion of the description of the functions of the sacred harlots into the story of the rebel and the king's elephant-that demonstrates that Indians are not merely curiosities, but agents of the purposes of providence.

I have used the word exotic freely; but if there is one thing that is striking in all the pieces discussed in this paper, it is that neither al-Tanūkhì nor his sources applies any word suggestive of wonder, strangeness, or exoticism to elephants or Indians-his strongest term is mathal 'ajami, "foreign parable"whereas even al-Birūnī calls the habits of the Indians an 'ujūba, "a cause of

71 Buzurg ibn Shahriyār 1883-1886: 164-165, no. CXI.

72 Bray 1998: 12-15. 
wonderment”. Al-Tanūkhī's "classification of the exotic", as I have mislabelled it, instead subordinates foreign or surprising materials to classification by storyline (in the case of Faraj), or to associative or dissociative grouping (in the case of Nishwār), and produces meaning from it by writing it in a certain way, descriptive or narrative, not by putting it in an epistemological box.

I took issue with André Miquel for evoking $a d a b$ to explain a fourth/tenthcentury narrative turn to the marvellous, on the grounds that his use of the term is not focussed enough to produce searching readings. I agree with Matar, Hermes and van Hees that "l'étrange et le merveilleux", sailors' and travellers' tales, and "the exotic" generally, are wrong or insufficiently examined categories, which modern scholarship has applied too loosely to an inadequately mapped literary field. Above all, I argue, they are not closed categories. Instances of the seemingly exotic cannot be read properly in isolation. Their intertextual, and hence cognitive and epistemological affinities, must be taken into account. As well as tales that hinge on physical diagnosis-medical, detective and adventure stories-biography and life writing should be brought into the picture, because of the technical and teleological similarities in the ways in which they use narrative and description to expand or illustrate what is probable or plausible in the knowledge we can gain of "the other".

Al-Tanūkhì's appropriation and development of the faraj ba'da al-shidda schema is now so familiar that we take it for granted, forgetting how original it was in its time, how vast an enterprise, and how much he achieved with it as a taxonomy of human experience serving to explore a theological truth (namely, that we are all agents of God's just but merciful providence). It has a contemporary parallel in the taxonomy of poetry devised by his fellow Basran, al-Hasan ibn Bishr al-Āmidī (d.371/987) in his al-Muwāzana bayna shi'r Abī Tammām wa-lBuhturī. This was an essay in practical criticism of unprecedented scope and scale: it sought to combine qualitative and quantitative criticism by "weighing" all of the poetry of Abū Tammām against that of al-Buhturī through minutely close readings of shared motifs, which are enumerated and examined in the sequences in which they occur in different poetic genres, and express the whole range of the truths about human feeling and imagination embodied in Arabic poetry. ${ }^{73}$ This had not been done before, just as al-Tanūkhì's anatomy of the thirteen types of adversity from which one can be delivered was a new approach to the classification of human experience and its narrative expression. Al-Āmidī's criticism was reader-centred: he wanted to make readers visualise poetic images fully, by retracing the processes through which successful, that is complete and saturated,

73 The enumeration starts at Al-Āmidī (1961-1965, 1990), vol.1: 430, with "Halting at the deserted campsite." See 'Abbās 1978: 147-185. 
images are created. ${ }^{74}$ In other words, he wanted to train them to be active close readers of poetry. For him, to read properly is to read thoroughly. In Nishwār and in Faraj, al-Tanūkhī too is training his readers to read properly, observantly, accurately and thoughtfully. He uses two opposite methods. In Nishwār, the reader, with no rubrics or set formats to guide him, has to do for himself all the work which he might expect the author to do for him of establishing thematic connections and transitions, and deciding what is the point of each item. In Faraj, where topics and their bearing are flagged up by al-Tanūkhī in his thirteen chapter headings, the reader is instead confronted in each chapter with variations on its central theme or on a sub-theme, and is required to pay close attention to details of wording and phrasing. ${ }^{75}$ In both Faraj and Nishwār, the reader must also pay attention to what has not been spelled out.

In the light of this, I would argue that the information, or knowledge, or understanding, that al-Tanūkhī is offering his readers is not primarily about content, astonishing though that content is in its concreteness and variety, but about how to read, and especially how to read stories, so as to perceive underlying truth, which, despite all appearances is, in his view, universal.

Acknowledgement: I should like to thank my anonymous reviewers for their remarks and suggestions.

\section{Bibliography}

'Abbās, Iḥsān (1978): Ta'rīkh Al-Naqd Al-Adabī 'Inda al-Arab. Beirut: Dār al-Amāna. al-Āmidī, al-Ḥasan ibn Bishr (1961-1965, 1990): al-Muwāzana Bayna Shi'r Abī Tammām wa-l-

Buțurī. Edited by Aḥmad Șaqr. Cairo: Dār al-Ma'āṛif, and Abd Allāh Ḥāmid Muḥārib. Cairo: al-Khānjī.

al-Bīrūnī, Abū Rayhān Muhammad ibn Aḥmad (1887): Alberuni’s India. An Account of the Religion, Philosophy, Literature, Chronology, Astronomy, Customs, Laws and Astrology of India about A.D. 1030. Edited by Edward Sachau. London: Trübner \& Co.

al-Damīrī, Muḥammad ibn Mūsā (1353): Ḥayāt Al-Hayawān Al-Kubrā. Cairo: Maṭba'at Ḥijāzī. al-Iṣfahānī, Abū Nu'aym Ạ̣mad ibn 'Abd Allāh (1932-1938): Ḥilyat Al-Awliyā'. Cairo: Maktabat al-Khānjī.

al-Jāḥiẓ, 'Amr ibn Baḥr (1938-1945): Kitāb Al-Hayawān. Edited by 'Abd al-Salām Muḥammad Ḥārūn. Cairo: Mușțafā al-Bābī al-Ḥalabī wa-awlāduhu.

al-Mas'ūdī, 'Alī ibn al-Ḥusayn (1966-1979): Murūj Al-Dhahab Wa-Ma'ādin Al-Jawhar. Edited by C. Barbier de Meynard and A. Pavet de Courteille. Revised by Charles Pellat. Beirut: alJāmi'a al-Lubnāniyya.

74 Ashtiany [Bray] 1983.

75 For descriptions of some examples not discussed here, see Bray 1998: 16. 
al-Sīrāfī, Abū Zayd (2014): Accounts of China and India. Edited and translated by Tim Mackintosh-Smith. New York: New York University Press.

al-Tanūkhi, al-Muhassin ibn 'Alī (1922): The Table-Talk of a Mesopotamian Judge. Translated by D.S. Margoliouth. London: The Royal Asiatic Society.

al-Tanūkhi, al-Muḥassin ibn 'Alī (1929): “The Table-Talk of a Mesopotamian Judge”. Translated by D.S. Margoliouth. Islamic Culture 3. October: 487-522.

al-Tanūkhi, al-Muḥassin ibn 'Alī (1930): "The Table-Talk of a Mesopotamian Judge”. Translated by D.S. Margoliouth. Islamic Culture 4. July: 363-388, October: 531-557.

al-Tanūkhi, al-Muḥassin ibn 'Alī (1932): “The Table-Talk of a Mesopotamian Judge”. Translated by D.S. Margoliouth. Islamic Culture 6. January: 47-66.

al-Tanūkhi, al-Muḥassin ibn 'Alī (1971-1973): Nishwār Al-Muhāẹara. Edited by 'Abbūd al-Shāljī. Beirut: Dār Șādir.

al-Tanūkhi, al-Muhassin ibn 'Alī (1978): al-Faraj Ba'da Al-Shidda. Edited by 'Abbūd al-Shāljī. Beirut: Dār Șādir.

al-Tha'ālibī, 'Abd al-Malik ibn Muḥammad (1983): Yatīmat Al-Dahr Fi Maḥāsin Ahl Al-'Așr. Edited by Mufĩd Muḥammad Qumayḥa. Beirut: Dār al-Kutub al-'Ilmiyya.

Arkoun, Mohammed (1978): L'Etrange et le merveilleux dans l'Islam médiéval. Actes du colloque tenu au Collège de France à Paris, en mars 1974. Paris: Institut du Monde Arabe.

Ashtiany [Bray], Julia (1983): The Muwāzana of al-Āmidī. D.Phil thesis, University of Oxford.

Bernus-Taylor, Marthe / Jail, Cécile (2001): L'étrange et le merveilleux en terre d'slam. Paris, Musée Du Louvre 23 Avril - 23 Juillet 2001. [n. p.]: Réunion des musées nationaux.

Blachère, Régis (1952-1966): Histoire de la littérature arabe des origines à la fin du XVe siècle de J.-C. Paris: Adrien-Maisonneuve.

Bray, Julia (2004): “Practical Mu'tazilism: The Case of al-Tanūkhī”. In: 'Abbasid Studies. Occasional Papers of the School of 'Abbasid Studies Cambridge 6-10 July 2002. Edited by James E. Montgomery. Leuven: Peeters, 111-126.

Bray, Julia (2006): “The Physical World and the Writer’s Eye: Al-Tanūkhī and Medicine”. In: Writing and Representation in Medieval Islam. Muslim Horizons. Edited by Julia Bray. London and New York: Routledge, 215-249.

Bray, Julia Ashtiany (1998): “Isnāds and Models of Heroes: Abū Zubayd Al-Ṭā'T̄, Tanūkhī’s Sundered Lovers and Abū '-'Anbas Al-Șaymarī”. Arabic and Middle Eastern Literatures 1.1: 7-30.

Ferrand, Gabriel (1922) (trans.): Voyage du marchand arabe Sulaymân en Inde et en Chine rédigé en 851 suivi de Remarques par abû Zayd Hasan (vers 916). Paris: Editions Bossard.

Hermes, Nizar (2013): “The Orient’s Medieval 'Orient(alism)': The Riḥla of Sulaymān al-Tājir as a Case Study”. In: Orientalism Revisted. Art, Land and Voyage. Edited by Richard Netton. London and New York: Routledge, 207-222. (Reproduced from Hermes (2012): The [European] Other in Medieval Arabic Literature and Culture. Ninth-Twelfth century AD. New York: Palgrave Macmillan, 11-37).

Kowalska, Maria (1987-1988): “From Facts to Literary Fiction: Medieval Arabic Travel Literature”. Quaderni Di Studi Arabi 5.6: 357-403.

Margoliouth, D.S.: see al-Tanūkhī (1922), (1929), (1930), (1932).

Matar, Nabil (2003): In the Lands of the Christians: Arabic Travel Writing in the Seventeenth Century. New York: Routledge.

Meisami, Julie Scott / Starkey, Paul (1998) (eds.): Encyclopedia of Arabic Literature. London and New York: Routledge.

Miquel, André (2001 [1967]): La Géographie humaine du monde musulman jusqu'au milieu du $11^{e}$ siècle, Vol. 1. Paris: Éditions de l’École des Hautes Études en Sciences Sociales. 
Miquel, André (2001 [1975]): La Géographie Humaine Du Monde Musulman Jusqu'au Milieu Du $11^{e}$ Siècle, Vol. 2: 1, 2. Paris: Éditions de l'École des Hautes Études en Sciences Sociales.

Miskawayh, Muhammad ibn Ahmad (1920-1921): The Eclipse of the 'Abbasid Caliphate: Original Chronicles of the Fourth Islamic Century. Translated by H.F. Amedroz and D.S. Margoliouth. Oxford: Basil Blackwell.

Petit, Odette, Voisin, Wanda (1993): Poèmes d'amour de 'Omar Ibn Abî Rabî‘a. [n. p.]: Publisud. Planhol, Xavier de (2000): L'Islam et la mer. La Mosquée et le matelot VII ${ }^{e}$-XX Siècle. Paris: Perrin.

Shahriyār, Buzurg ibn (1883-1886): 'Ajā'ib al-Șinn wa-l-Hind. Livre des merveilles de l'Inde par le Capitaine Bozorg fils de Chahriyâr de Râmhormuz. Edited by P. A. van der Lith. Translated by L. Marcel Devic. Leiden: E. J. Brill.

Van Gelder, Geert (2003): "To Eat or Not to Eat Elephant: A Travelling Story in Arabic and Persian Literature". Bulletin of the School of Oriental and African Studies 66.3: 419-430.

Van Hees, Syrinx (2017): "Meaning and Function of 'ajā'ib in Writing on Mamluk Historiography and in Mamluk Historical Writing Itself". In: Inhițāț-The Decline Paradigm: Its Influence and Persistence in the Writing of Arab Cultural History. Edited by van Hees, Syrinx. Würzburg: Ergon Verlag, 173-192.

Wilkinson, J. C. (1974): "Bayāsirah and Bayādīr". Arabian Studies 1: 75-85. Wink, André (1990): Al-Hind: The Making of the Indo-Islamic World, Vol. 1. Leiden: Brill. Yāqūt (1990): Mu'jam Al-Buldān. Edited by Iṇsān 'Abbās. Beirut: Dār al-Kutub al-'Ilmiyya. Yule, Henry / Burnell, A.C. (1968 [1903]): Hobson-Jobson. A Glossary of Colloquial Anglo-Indian Words and Phrases, and of Kindred Terms, Etymological, Historical, Geographical and Discursive. Edited by William Crooke. Delhi: Munshiram Manoharlal. 